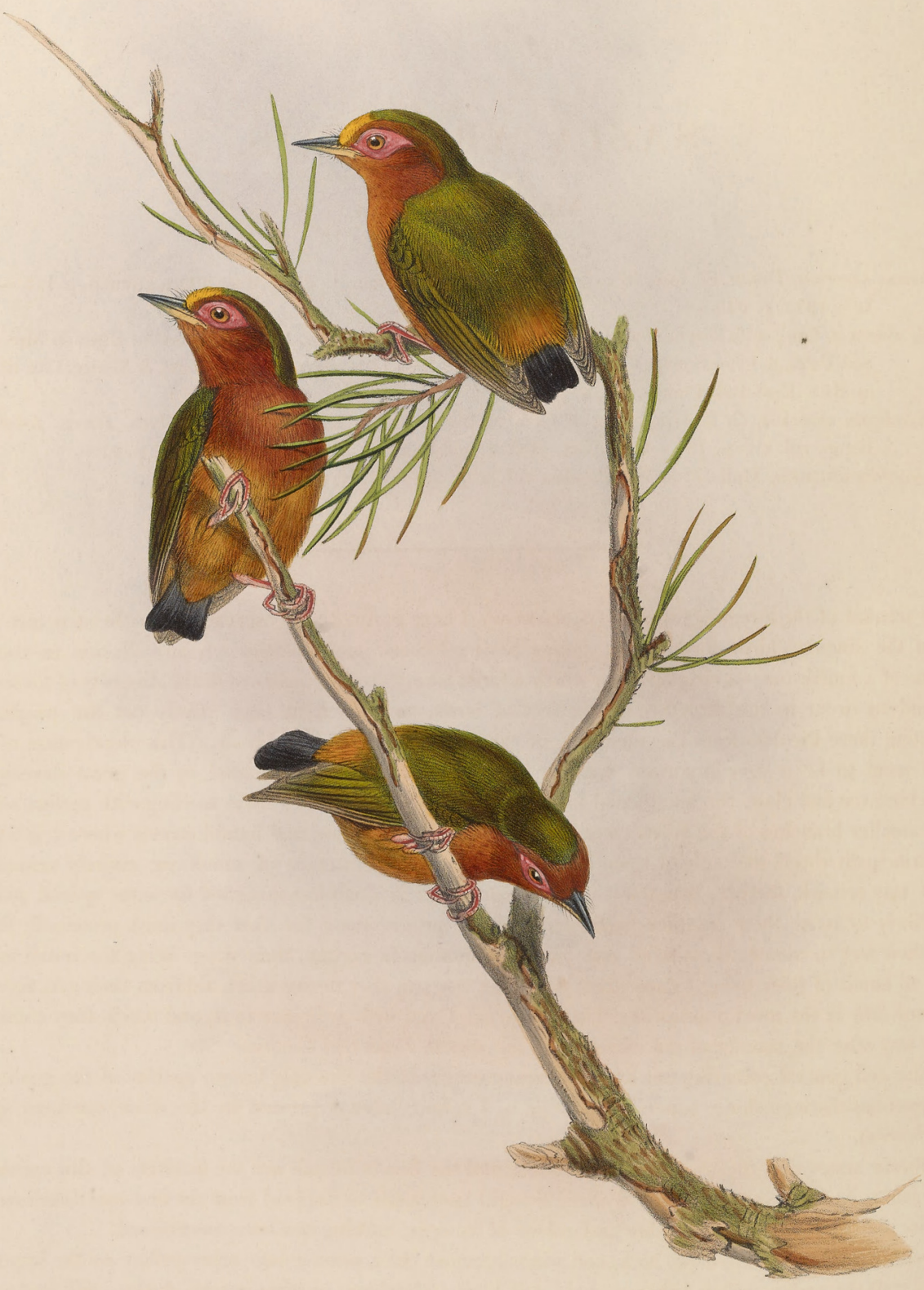




\section{SASIA ABNORMIS.}

\section{Malayan Piculet.}

Picumnus abnormis, Temm. Pl. Col., 371. fig. 3.-Less. Traité d'Orn., p. 231; Man. d’Orn., tom. ii. p. 115.-Wagl. Isis, 1829 , p. 646

Sasia abnormis, Gray and Mitch. Gen. of Birds, vol. ii. p. 433, Sasia, sp. 1.-Blyth, Cat. of Birds in Mus Asiat. Soc. Calc., p. 65.-Bonap. Consp. Gen. Av., tom. i. p. 140, Sasia, sp. 1.-Horsf. \& Moore, Cat. of Birds in Mus. East-Ind. Comp., vol. ii. p. 678.

Microcolaptes abnormis, G. R. Gray, List of Gen. of Birds, p. 54 ; 2nd edit., p. 70.-Blyth, Journ. Asiat. Soc. Beng., vol. xiv. p. 191.-Gray, Cat. of Gen. and Subgen. of Birds in Brit. Mus., p. 91.

Picumnoides abnormis, Malh. Mon. des Picidés, vol. ii. p. 286, vol. iv. pl. 115. fig. 1.

In my account of the foregoing species (S. ochracea), I have omitted any observations on the structure of the feet of the singular birds forming the genus Sasia; I mean more particularly any allusion to the total absence of a fourth toe- a circumstance which affords a very striking instance of the diversity of form which is found to occur in the structure of the feet of birds, and which at once points out the propriety of separating these Piculets from the members of the genera Vivia and Picummus. This deprivation of what would seem to be a very important member appears to be fully compensated by the great development of the hind toe and claw, the lengthened form of which doubtless enables them to cling with perfect security to the smaller branches of the fallen trees lying prostrate in the dense and humid forests where it is believed they principally dwell, and subsist upon insects the forms and structure of which are entirely unknown to us. I may remark, further, that this singular deprivation is doubtless designed for some special purpose, most likely to assist them in some particular mode of progression; for that they must principally depend upon their feet to remove them from one place to another is certain, their wings being too round and too feeble to admit of their flying to any great distance; nor can they derive much aid from their tail, for which the word little is the most appropriate that can be employed with reference to it, and which they cannot use in any way after the manner of the members of the genera Picus and Certhia.

In size and general colouring but little difference occurs in the two only known species of the genus; but a conspicuous distinguishing, superciliary stripe is, I believe, always present in the more northern species (S. ochracea).

Malherbe states that the peninsula of Malacca and the Sonda Islands are the habitats of this species; it is also said to be found in Java. Mr. Wallace bronght specimens to England from the first-mentioned country.

Of its nidification, and the number and colour of its eggs, nothing has been ascertained.

Forehead yellow; crown, nape, back, and wings greenish olive, passing into ochre-yellow on the upper tailcoverts; all the under surface ochreous red; tail black; shoulders or wing-coverts dusky ; bill lead-colour, becoming yellowish on the base of the under mandible; irides pale brown; naked orbits red; feet pale red.

The figures are of the natural size. 


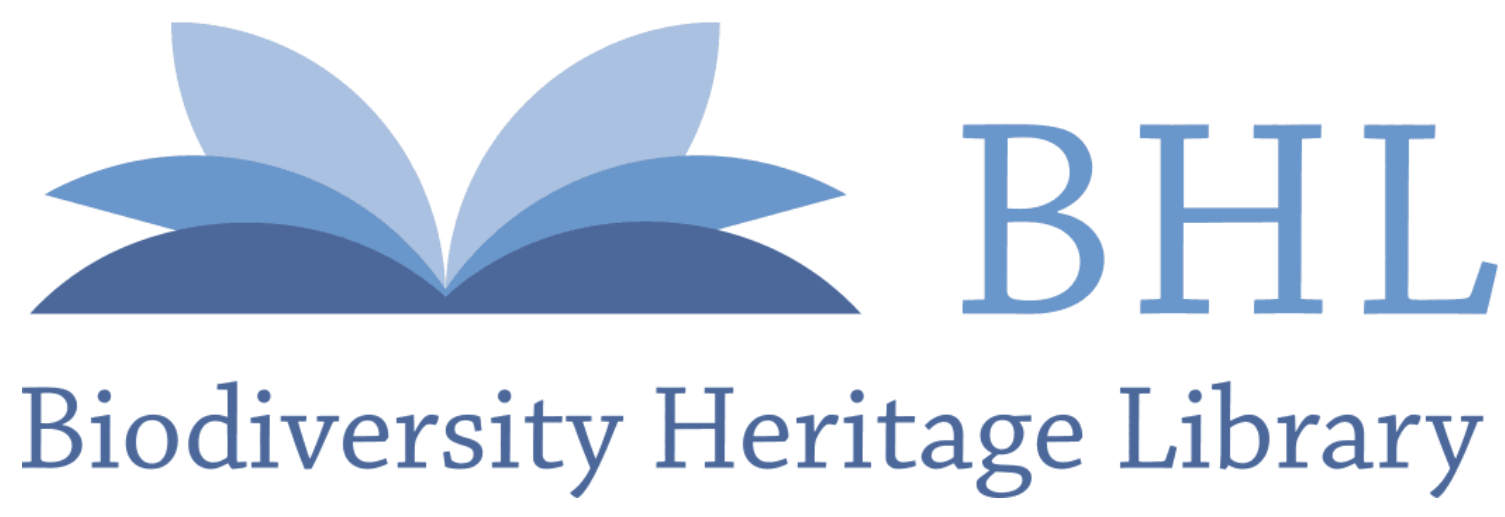

Gould, John. 1870. "Malayan Piculet, Sasia abnormis [PI. 41]." The Birds of Asia 6(XXII), -. https://doi.org/10.5962/p.323468.

View This Item Online: https://www.biodiversitylibrary.org/item/122488

DOI: https://doi.org/10.5962/p.323468

Permalink: https://www.biodiversitylibrary.org/partpdf/323468

\section{Holding Institution}

Smithsonian Libraries

\section{Sponsored by}

Smithsonian Institution Libraries

\section{Copyright \& Reuse}

Copyright Status: Not in copyright

This document was created from content at the Biodiversity Heritage Library, the world's largest open access digital library for biodiversity literature and archives. Visit BHL at https://www.biodiversitylibrary.org. 